Chirurgia (2017) 112: 387-393

No. $4, \quad$ July - August

Copyright@ Celsius

http://dx.doi.org/10.21614/chirurgia.112.4.387

\title{
Immediate-DElayed AutoLogous (IDEAL) Breast Reconstruction with the DIEP Flap
}

\author{
Sonia Fertsch, Beatrix Munder, Mazen Hagouan, Tino Schulz, Oliver Thamm, Peter Stambera, \\ Alina Abu-Ghazaleh, Julia Schaberick, Christoph Andree
}

Department of Plastic and Aesthetic Surgery, SANA Krankenhaus Düsseldorf Gerresheim, Germany

Corresponding author:

Sonia Fertsch, MD

Department of Plastic and Aesthetic

Surgery, SANA Krankenhaus

Düsseldorf Gerresheim, Germany

E-mail: soniafertsch@gmail.com

\section{Rezumat}

Reconstructia mamară în două etape cu țesut autolog (IDEAL) cu lambou DIEP

Context: Cancerul de sân este cel mai frecvent tip de cancer la femei la nivel mondial. Numărul tot mai mare de cazuri în fiecare an necesită o abordare curativă nouă care poate combina tratamente oncologice şi reconstrucția sânului, cu rezultate plăcute şi estetice, fiind o soluție definitivă şi de lungă durată. Aşadar, a fost creat principiul IDEAL în reconstrucția mamară, care să se potrivească standardelor şi nevoilor femeilor de astăzi.

Metodă: Protocolul IDEAL pentru reconstrucția mamară a fost dezvoltat în departamentul nostru, în colaborare cu departamentul de chirurgie a sânului, şi descrie o abordare în două etape care implică tratament cu radio/chimioterapie neoadjuvantă şi stadializarea tumorii înainte de mastectomie, pentru evitarea radierii post-mastectomie. A doua etapă presupune reconstrucția mamară cu țesut autolog pentru rezultate naturale şi optime.

Concluzie: Tot mai multe paciente decid să beneficieze de reconstrucție mamară după cancerul de sân. Conceptul IDEAL oferă o soluție de lungă durată şi în condiții de siguranță, cu o rată scăzută a complicațiilor tardive.

Cuvinte cheie: protocol IDEAL, reconstrucția mamară, cancer de sân, tratament cu radio-/chimioterapie neoadjuvantă 


\begin{abstract}
Background: The most common cancer worldwide in women is breast cancer. The increasing number of cases each year, requires a novel curative approach that can combine oncological treatments and breast reconstruction yielding a pleasing and aesthetic breast that is a definitive and long lasting solution. Thus, the Immediate-DElayed AutoLogous (IDEAL) breast reconstruction principle was created to hold up to the standards of the needs of contemporary women.

Method: The IDEAL protocol for breast reconstruction was developed in our department in cooperation with our breast surgery unit and describes a two-stage approach that implicates neoadjuvant radio-/ chemotherapy treatment regimes and tumor staging before the mastectomy in order to avoid post-mastectomy radiation. In a second step the breast is then reconstructed with autologous tissue for optimal and natural results.

Conclusion: More and more patients decide to undergo breast reconstruction after breast cancer. The IDEAL concept offers a life-long and safe solution with a low rate of late complications.
\end{abstract}

Key words: IDEAL Method, DIEP, breast reconstruction, breast cancer, neoadjuvant treatment

\section{Introduction}

Worldwide, the most common cancer in women is breast cancer. The lifetime risk for breast cancer is up to $10 \%$ in women without any familiar predisposition (1). Yet, in women who carry the BRCA1/2 gene, the risk of breast cancer is drastically increased to up to $89 \%$ (2). In 2012, statisticians estimated 226,870 new cases of invasive breast cancer among women in the US with 63,000 new cases of ductal carcinoma in situ (3). Between the years 2005 and 2011, the mastectomy rate for women with breast cancer was $51 \%$ with a steady increasing number of patients receiving bilateral prophylactic risk-reducing mastectomies in case of increased breast cancer risk (4). This patient cohort is mainly composed of young women who need a definitive and especially long lasting solution for breast reconstruction. Initially breast reconstruction starts as a reconstructive procedure but transforms into being aesthetic in the end because patients have high expectations and would like to not only have a breast but also a breast with an appealing and attractive look. Yet, oncological safety is the highest priority that at the same time poses a challenge for the surgeon in terms of the aesthetic outcome of the procedure. The extend of mastectomy varies and adjuvant chemo- and/or radiotherapy can alter the results and induce postoperative complications that are not seldom associated with pain due to e.g. capsular contracture in case of radiotherapy before and or/after implant based reconstruction (5). Surgeons often have to deal with irradiated tissues, especially if a recurrence has occurred after breast conservative surgery. Placing an implant in bad tissue conditions is often associated with an increased risk of wound healing difficulties up to the point of tissue necrosis and implant exposure. In addition painful capsular contracture can occur more often in irradiated breast making the tissue to be unsuitable for implant breast reconstruction $(5,6)$. Thus, reconstructive procedures require a multidisciplinary approach taking the all options into consideration:

\section{Immediate Implant-based Reconstruction}

Neoadjuvant radiotherapy and/or chemotherapy is often performed after a lumpectomy in breast conserving therapy or before mastectomy. Depending on which form of mastectomy is chosen (either Nippel Skin Sparing Mastectomy or total mastectomy), the breast can be reconstructed immediately using an implant which is placed behind the pectoralis major muscle to increased the tissue thickness overlying it (7). 
Nevertheless, the tissue quality of the breast is not good and immediate complications may arise in form of wound healing difficulties resulting in a poor aesthetic outcome or late complications such as capsular contracture. Sometimes the patient still requires adjuvant radiotherapy, for example in case of accidental cancer findings in the removed breast parenchyma. The implant approach often requires a second surgical intervention in form of implant changes.

\section{Delayed Implant-based Reconstruction}

There is also the possibility to implant an expander as an immediate reconstructive step and after completion of the adjuvant treatment exchange it for an implant. Yet, often the skin of the tissue envelope is very thin and fragile causing wound healing problems and capsular contracture in a long run (8).

\section{Immediate Autologous Tissue Reconstruction}

Another option is the use of autologous tissue instead of alloplastic material. There are pediculated or free autologous tissue flaps that are divided into the latissimus dorsi- and the Transverse Rectus Abdominis Myocutaneous (TRAM) - flap reconstruction or the free microsurgical flaps as the Deep Inferior Epigastric Perforator (DIEP) - flaps, Transverse Myocutaneous Gracilis (TMG)-flaps and Gluteal Artery Perforator (GAP) - flaps (9). At times the latissmus dorsi flap can be used together with an implant reconstruction in order to augment the tissue thickness above the implant in case of poor tissue quality of the skin envelope (10). After a skin sparing mastectomy (SSM) or total mastectomy the breast can be reconstructed immediately with autologous tissue. Yet, the timing of the reconstruction is often close to the end of radio-/chemotherapy, causing not optimal tissue circumstances. The tissue envelope of the breast may shrink unpredictably and the need of post- reconstructive radiotherapy may cause fat necrosis and flap shrinkage causing breast asymmetry. In addition, it is hard to foresee potential perfusion problems of the breast skin after NSM/SSM in which the flap is placed into. Thus post-surgical necrotic areas become a complication with further surgical interventions such a skin grafting onto the given zone (11).

\section{Delayed Autologous Tissue Reconstruction}

This approach combines alloplastic material in form of expanders or implants by using them as spacers inside the breast skin envelope to avoid the skin to stick back to the thoracic wall after mastectomy has been performed. Once the oncological treatment is completed, the implant can be removed and substituted with autologous tissue or the expander is being filled to enlarge the breast skin for a larger autologous tissue flap insertion (12).

Breast reconstruction is a multidisciplinary approach and has to take all the above-mentioned possibilities into account to achieve the safest, but also aesthetically satisfying option for the patient taking into consideration to avoid potential late complication. Also, the timing of breast reconstruction is of high importance and the decision between immediate vs delayed reconstruction should be well analyzed in a multidisciplinary approach together with the oncologist to avoid post-mastectomy irradiation.

\section{Method}

Since it is still challenging to predict the probability of necessity of post-mastectomy radiation, immediate breast reconstruction might not be the best approach for each case (13).

Over the years many sequences have developed to unify oncological treatment and breast reconstruction. The need for postmastectomy radiation therapy cannot be determined until the pathologist has reviewed permanent tissue sections. Thus one study has proposed a delayed-immediate method, which implements a two-stage approach to optimize reconstruction in patients at risk for requiring post-mastectomy radiation therapy (14). The first stage is composed of a skin sparing mastectomy with the insertion of a maximal filled textured tissue expander. After deter- 
mining the oncological status of the tissue parenchyma, patients with negative results, who do not require post-mastectomy radiation move to stage 2 of the protocol where they undergo immediate reconstruction within a week of obtaining the histo-pathological results. Patients, who required radiation, complete the oncological treatment during which the tissue expander was deflated. Upon completion, it is being reinflated maximally again. Then patients obtaine their delayed breast reconstructive procedure in stage 2 . The tissue expanders in the study were placed subpectorally and one subcutaneously which had to be removed after radiation due to skin necrosis. In this protocol the breast reconstructive technique was not standardized and all forms of reconstruction were used ranging from implantbased reconstruction to latissimus dorsi flap with implant or TRAM.

The Immediate DElayed AutoLogous (IDEAL) protocol (Fig. 1) for breast reconstruction, which was developed in our department in cooperation with our breast surgery unit implicates neoadjuvant radio-/ chemotherapy treatment regimes and staging before the mastectomy (15). In the very first place the tumor is being removed and the sentinel lymph node biopsy is taken in order to be able to stage the tumor following further diagnostic work up as mammography or MRI in order to avoid post-mastectomy radiation. If there is an indication for neoadjuvant chemo-/radiotherapy, the patient undergoes the regime and obtains a NSM with implant insertion if oncological safety is warranted. If no therapy is needed the patients proceed right away to the NSM and implant insertion if mastectomy is indicated or tumorectomy has left the breast with an aesthetically non-pleasing result. Excess skin by ptotic or big breasts can be resected and the skin enveloped reshaped. The implant is placed preferably epipectoral in preparation for autologous tissue reconstruction with the DIEP-flap, the golden standard in our department. In case the patient prefers implant-

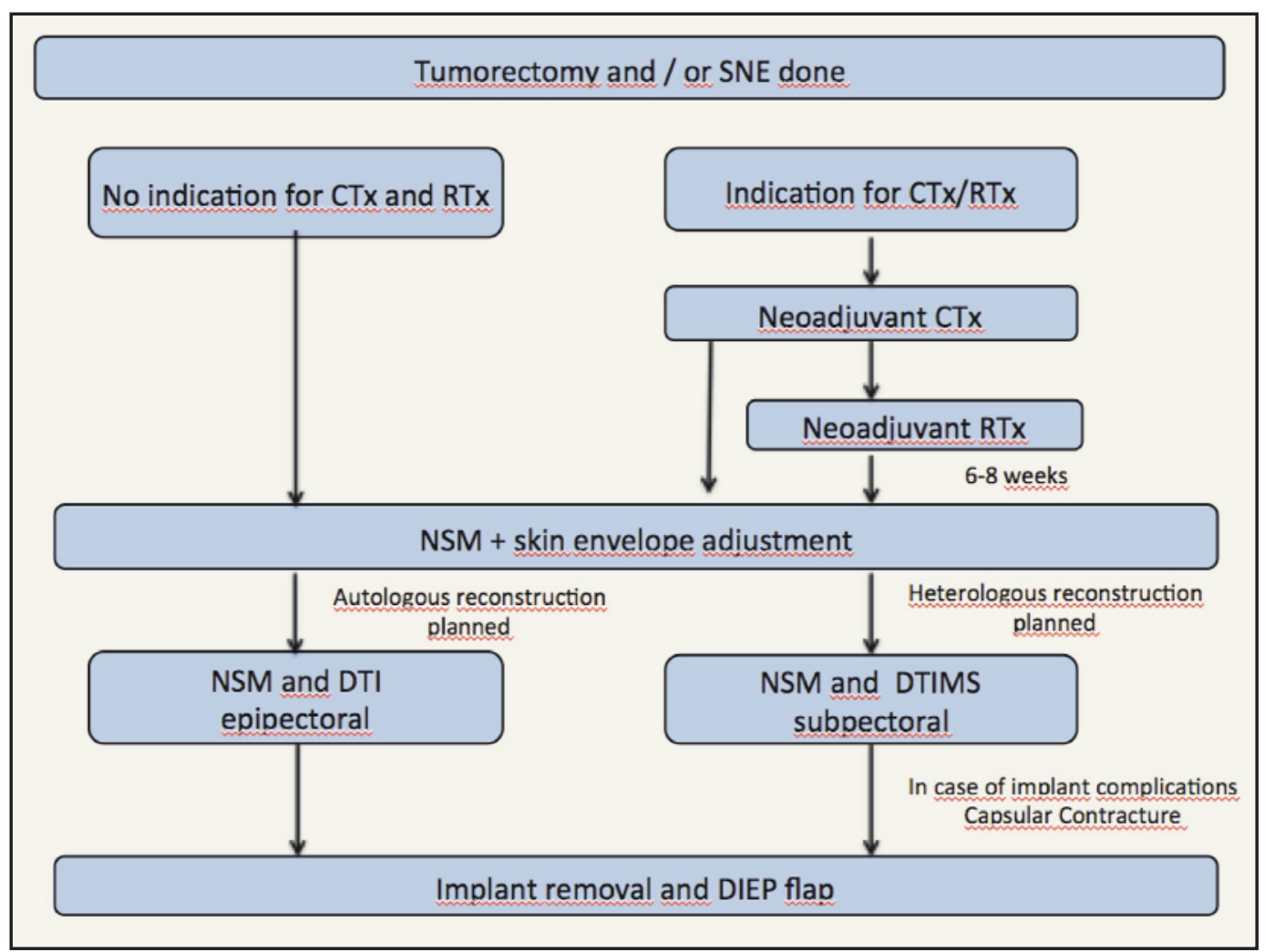

Figure 1. Immediate DElayed AutoLogous breast reconstruction (IDEAL) protocol 


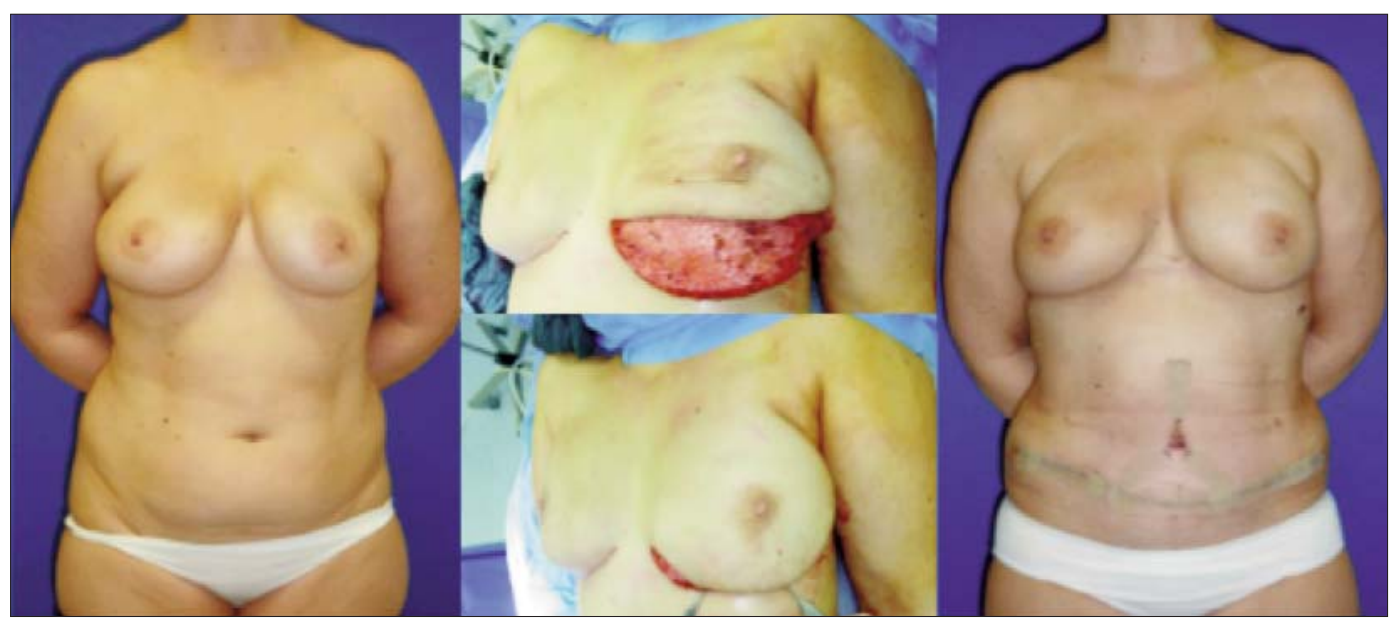

Figure 2. The DIEP-flap procedure

based reconstruction, the implant is placed subpectoral and reinforced with a mesh. In case of implant complications such as capsular contracture, the implant can be removed with the capsule and mesh, the pectoralis muscle is then sutured back to the thoracic wall and the DIEP flap is place epipectorally in the former implant pocket. In case cancer remnants have been found in the mastectomy specimen, a reresection follows the procedure or if non-tumor free margins have been found in the retroareolar region, the Nippel Areola Complex (NAC) is resected. In both scenarios the implanted is exchanged for a structured tissue expander to later enlarge the skin envelope to obtain a symmetrical result if necessary. Ideally the whole DIEP-flap is covered underneath the skin pocket of the breast (Fig. 2).
The first picture shows a woman with a capsular contracture after bilateral implant based reconstruction after breast cancer.

Once microsurgical anastomosis was performed, the whole tissue flap is inserted inside the skin envelope where the implant was previously situated.

The last picture shows the woman postoperatively after her DIEP-flap procedure.

Yet, if the breast form needs improvement or more projection, a skin island from the DIEP-flap is then being incorporated into the skin envelope to reshape the breast (Fig. 3).

Picture (left) shows a patient after breast conservative therapy and radiation after breast cancer on the left side before breast reconstruction.

Picture (right) demonstrates the same

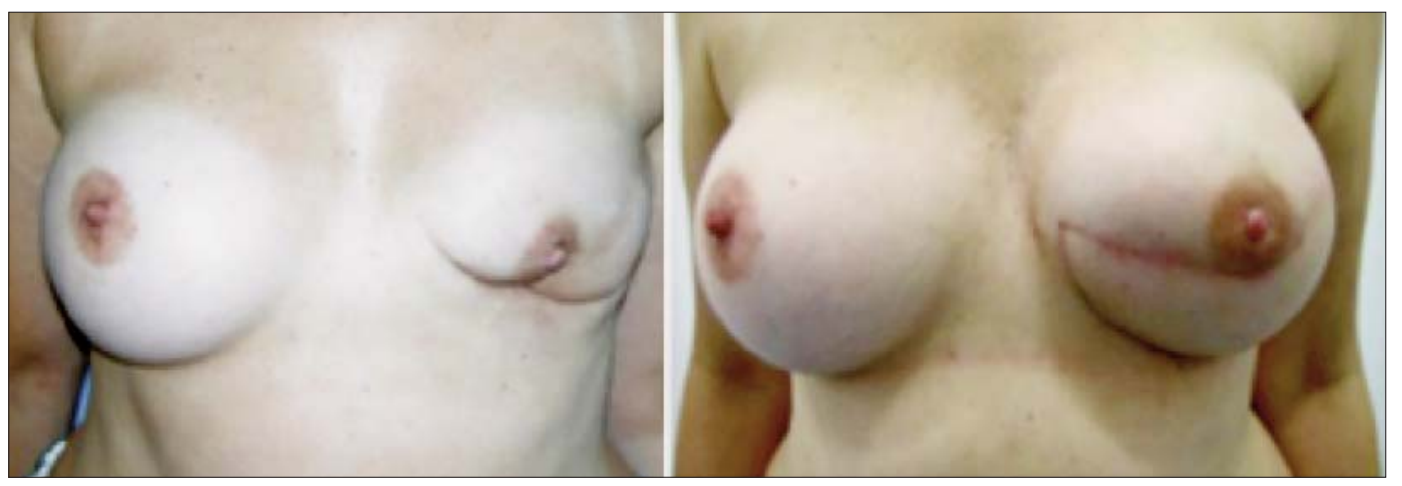

Figure 3. The monitoring skin island 
patients after DIEP-flap breast reconstruction with a skin island for volume restoration.

When a tissue expander was inserted into the breast, we tend to expand the skin more than it is necessary because radiated skin tends to shrink and thus can compress the autologous tissue flap resulting in a breast asymmetry.

Nevertheless if symmetricalisation procedures are needed, they can be performed 6 months after the autologous breast reconstruction by the means of a mamma reduction plasty of the contralateral side and a nipple reconstruction. The latter is reconstructed with a star flap (16) and the nipple areola complex is then tattooed. Sometimes, intra-operatively, the perfusion of the breast envelope can be poor due to the low skin thickness after the removal of the implant together with its capsule. Then, the DIEP-tissue is inserted temporarily into the skin pocket as a non-epithelialized flap, giving the skin the chance to either recover or demark the necrotic zones, which will be then excised and substituted with the underlying skin from the DIEP-flap. Thus the concept of delayed de-epithelialization is a helpful tool to prevent poor outcomes with skin necrosis and extensive scaring and saves the patients unnecessary re-operations and complications (17).

\section{Discussion}

Where reconstruction can be done with a low morbidity, such that systemic therapy and post-radiation therapy will not be delayed, it is possible to perform immediate breast reconstruction. However, the type of reconstruction performed should not be allowed to interfere with delivering loco-regional and systemic treatments (18). In the study of Motwani et al. it was concluded that immediate breast reconstruction poses challenges for the treatment planning of post mastectomy radiation therapy because of suboptimal field coverage and organ protection (19). Also, patients who have their breast reconstructed before their radiotherapy are exposed to increased late complication rates (20) and unpredictable outcomes (21) due to which the timing of breast reconstruction has to be planned carefully. Patients that receive radiotherapy after DIEP-flap reconstruction show significantly increased rates of fat necrosis, fibrosis and contracture (21), similar applies to implant based reconstruction (22, 23). Thus it is of advantage to perform first a lumpectomy with sentinel lymph node biopsy in order to be able to establish neoadjuvant chemo- and/ or radiotherapy since there are increased rates of postoperative complications described following post-mastectomy radiotherapy. Neoadjuvant radiotherapy aims to improve the aesthetic results and simplify the reconstructive pathway. The possibility to perform a NSM/SSM with an implant insertion gives the patients at this point the freedom to choose which type of reconstruction they prefer leaving them with no flat chest and no delay in oncological therapy and with safe resection margins. Once the patient has decided for either autologous or alloplastic reconstruction, the mastectomy is performed and the implant is placed either epi- or subpectoral. When the patient opts for an autologous approach, the reconstruction follows after $4-6$ months after the mastectomy to ensure a proper and reliable skin envelope quality. Another advantage is that the skin envelope can be adjusted or even the inframammary fold corrected if necessary. There is enough time for a good planning of the autologous reconstruction. Since, secondly, after the oncological and patient safety, the patient quality of life and cosmetics play another role in the well-being of the patient and influence their choice for additional reoperations. The disadvantage of the concept is that there are certainly 2 surgeries needed in case of autologous breast reconstruction and there are also abdominal scars at the donor site in case of the DIEP-flap but at the same time, patients with an excess amount of abdominal tissue profit from procedure by obtaining automatically an abdominoplasty. The IDEAL concept does not guarantee no late complications but definitively minimizes their appearance and is considerable approach to the problem of systemic/local oncological therapy combined with breast reconstruction with good aesthetic 
outcomes. Yet, in any case, cosmetics should not take precedence over the oncologic considerations.

\section{References}

1. Otte $M$, Nestle-Krämling $C$, Fertsch $S$, Hagouan $M$, Munder $B$, Richrath $\mathrm{P}$, et al. Conservative mastectomies and ImmediateDElayed AutoLogous (IDEAL) breast reconstruction: the DIEP-flap. Gland Surg. 2016;5(1):24-31. doi: 10.3978/j.issn.2227684X.2015.05.15

2. Antoniou AC, Durocher F, Smith P, Simard J, Easton DF; INHERIT BRCAs program members. BRCA1 and BRCA2 mutation predictions using the BOADICEA and BRCAPRO models and penetrance estimation in high-risk French-Canadian families. Breast Cancer Res. 2006;8(1):R3. Epub 2005 Dec 12.

3. www.cancer.org/statistics.

4. Lucas DJ, Sabino J, Shriver CD, Pawlik TM, Singh DP, Vertrees AE. Doing more: trends in breast cancer surgery, 2005 to 2011. Am Surg. 2015;81(1):74-80

5. Cordeiro PG, Pusic AL, Disa JJ, McCormick B, VanZee K. Irradiation after immediate tissue expander/implant breast reconstruction: outcomes, complications, aesthetic results, and satisfaction among 156 patients. Plast Reconstr Surg. 2004;113(3):877-81.

6. Kim SW, Lee HK, Kang SM, Kang TH, Yoon CS, Ko SS, et al. Shortterm outcomes of immediate breast reconstruction using an implant or tissue expander after mastectomy in breast cancer patients. Breast Cancer. 2016;23(2):279-85. doi: 10.1007/s12282014-0570-y. Epub 2014 Oct 22.

7. Evans GR, Schusterman MA, Kroll SS, Miller MJ, Reece GP, Robb $\mathrm{GL}$, et al. Reconstruction and the radiated breast: is there a role for implants? Plast Reconstr Surg. 1995;96(5):1111-5; discussion, 1116-8.

8. Romics L Jr, Stallard S, Weiler-Mithoff E. Oncologic safety of skinsparing mastectomy followed by immediate breast reconstruction: rate and localization of recurrences, and impact of reconstruction techniques Orv Hetil. 2013;154(5):163-71. doi: 10.1556/0H.2013. 29529. Hungarian

9. Teymouri H, Stergioula S, Eder M, Kovacs L, Biemer E, Papadopulos N. Breast reconstruction with autologous tissue following mastectomy. Hippokratia. 2006;10(4):153-62.

10. Lee J, Bae Y. Use of latissimus dorsi muscle onlay patch alternative to acellular dermal matrix in implant-based breast reconstruction. Gland Surg. 2015;4(3):270-6. doi: 10.3978/j.issn.2227684X.2015.01.07
11. Schaverien MV, Macmillan RD, McCulley SJ. Is immediate autologous breast reconstruction with postoperative radiotherapy good practice?: a systematic review of the literature. J Plast Reconstr Aesthet Surg. 2013;66(12):1637-51. doi: 10.1016/j.bjps.2013.06. 059. Epub 2013 Jul 22.

12. Nestle-Krämling C, Bölke E, Budach W, Andree C. Erratum to: Breast reconstruction after neoadjuvant radio chemotherapy: review and personal technique IDEAL concept. Eur J Med Res. 2016;21(1):30

13. Schaverien MV, Macmillan RD, McCulley SJ. Is immediate autologous breast reconstruction with postoperative radiotherapy good practice?: a systematic review of the literature. J Plast Reconstr Aesthet Surg. 2013;66(12):1637-51. doi: 10.1016/j.bjps.2013.06. 059. Epub 2013 Jul 22.

14. Kronowitz SJ, Robb GL. Breast reconstruction with postmastectomy radiation therapy: current issues. Plast Reconstr Surg. 2004;114(4): 950-60.

15. Anton MA, Eskenazi LB, Hartrampf CR Jr. Nipple reconstruction with local flaps: star and wrap flaps. Seminars in Plastic Surgery 1991;5:67-78.

16. Guven E, Ozden BC, Basaran K, Keklik B. Delayed deepithelization of the chestwall skin: a cautious approach in perforator flap breast reconstruction. Microsurgery. 2010;30(7):589-90. doi: 10.1002/ micr.20802.

17. Roughton MC, Shenaq D, Jaskowiak N, Park JE, Song DH. Optimizing delivery of breast conservation therapy: a multidisciplinary approach to oncoplastic surgery. Ann Plast Surg. 2012;69(3):250-5. doi: 10.1097/SAP.0b013e31822afa99.

18. Motwani SB, Strom EA, Schechter NR, Butler CE, Lee GK, Langstein $\mathrm{HN}$, et al. The impact of immediate breast reconstruction on the technical delivery of postmastectomy radiotherapy. Int $\mathrm{J}$ Radiat Oncol Biol Phys. 2006:66(1):76-82. Epub 2006 Jun 9.

19. Garvey PB, Clemens MW, Hoy AE, Smith B, Zhang H, Kronowitz SJ, et al. Muscle-sparing TRAM flap does not protect breast reconstruction from postmastectomy radiation damage compared with the DIEP-flap. Plast Reconstr Surg. 2014;133(2):223-33. doi: 10.1097/01.prs. $0000436845.92623 .9 \mathrm{a}$.

20. Rogers NE, Allen RJ. Radiation effects on breast reconstruction with the deep inferior epigastric perforator flap. Plast Reconstr Surg. 2002;109(6):1919-24; discussion 1925-6.

21. Cordeiro PG, Pusic AL, Disa JJ, McCormick B, VanZee K. Irradiation after immediate tissue expander/implant breast reconstruction: outcomes, complications, aesthetic results, and satisfaction among 156 patients. Plast Reconstr Surg. 2004;113(3):877-81.

22. Ascherman JA, Hanasono MM, Newman MI, Hughes DB. Implant reconstruction in breast cancer patients treated with radiation therapy. Plast Reconstr Surg. 2006;117(2):359-65. 